Nygård, E. F., Wondimu, P., Lædre, O. (2019). "Best Value Procurement - Experiences from the Execution Phase" In: Proc. $27^{\text {th }}$ Annual Conference of the International. Group for Lean Construction (IGLC), Pasquire C. and Hamzeh F.R. (ed.), Dublin, Ireland, pp. 109-120. DOI: https://doi.org/10.24928/2019/0170. Available at: 〈www.iglc.net>.

\title{
BEST VALUE PROCUREMENT - EXPERIENCES FROM THE EXECUTION PHASE
}

\author{
Emil Fløvik Nygård ${ }^{1}$, Paulos Wondimu ${ }^{2}$, and Ola Lædre ${ }^{3}$
}

\begin{abstract}
Best value procurement (BVP) is one of the approaches for early contractor involvement (ECI) in public construction projects. Despite an increased number of projects using the approach, there is a lack of knowledge regarding use of BVP in the Norwegian construction industry. Little research has been done on the consequences due to BVP, and the approach is often misinterpreted as only a procurement model. However, BVP provides an important mind-set for all parties involved, also during the execution phase. This paper study how BVP is practiced in two public kindergarten projects, what consequences that followed in the execution phase, and how BVP should be practiced in future projects. In addition to a literature study, the two projects were studied through a longitudinal study consisting of 8 in-depth semi-structured interviews and a document study. The findings show that how elements of BVP are practiced in the early phases influences both the execution phase and the final product. This study has developed important measures and improvements for how to practice $\mathrm{BVP}$, and is among the first to document experiences from the execution phase. The identified measures can lead to a better execution phase, and thus a better product for the client.
\end{abstract}

\section{KEYWORDS}

Best value procurement (BVP), early contractor involvement, value, standardization, execution phase

\section{INTRODUCTION}

Statistics given by Statistics Norway (2018) shows a 10\% decrease in productivity in the Norwegian construction industry since year 2000. Despite a large focus on project management and project analysis there are numerous projects being completed after deadline, over budget, not within project targets or aborted before completion (Samset, 2014). Several approaches are applied to turn this trend over, such as partnering and early contractor involvement (ECI). Partnering is characterized by trust, open and effective

$1 \quad$ M. Sc. Student, Department of Civil and Environmental Engineering (DCEE), Norwegian University of Science and Technology (NTNU), Trondheim, Norway, emilfn@ stud.ntnu.no

2 Researcher, DCEE, NTNU, NTNU / Senior Engineer, Norwegian Public Roads Administration, Norway, paulos.wondimu@ntnu.no / paulos.wondimu@ vegvesen.no

3 Professor, DCEE, NTNU, Trondheim, Norway, ola.ladre@ntnu.no 
communication, common goals and early involvement of suppliers (Hosseini et al. 2018). There are several approaches for implementing ECI in the public sector and BVP is one of them (Wondimu et al. 2018b). BVP seeks to facilitate an efficient procurement where the vendor delivers according to the client's project ambitions, reduces the client's risk and minimizes the stakeholders' use of resources (van de Rijt et al. 2016). BVP is a part of the Best Value Approach (BVA) founded by Dean Kashiwagi in 1991, and consists of a procurement model, a risk managing model and a project management model (Kashiwagi, 2016). The available research is mainly related to the early phases of BVP, and minimal research has been done on the execution phase and how BVP can improve the final product. Therefore, this paper explores experiences from the execution phase of two Norwegian building projects and addresses the following research questions:

- How was BVP practiced through the projects?

- What consequences followed BVP in the execution phase?

- How should BVP be practiced to improve the execution phase and the final product?

The study is limited to two Norwegian public kindergarten projects and the results are limited to experiences from the winning actors. Both projects have the same client and the study is not extended to explore other actors' experiences such as the losing vendors, subcontractors and consultants.

\section{RESEARCH METHOD}

The research was carried out based on a literature review and two longitudinal case studies. A qualitative case study provides tools for researchers to study complex phenomena within their contexts (Baxter \& Jack, 2008), whereas a longitudinal study consists of continuous or repetitive measures to follow particular individuals over prolonged periods of time (Caruana et al. 2015). The method was chosen in order to reveal time-dependent patterns and document changes and experiences over time. A longitudinal study requires the presence of three conditions; (1) that data is collected during two or more time periods; (2) comparable individuals; and (3) that the analysis involves comparison of data from two or more time periods (Garcia-Pena et al. 2015). All conditions were fulfilled by the chosen case projects, and the two cases were chosen as they are among the first building projects in Norway using BVP. The two projects were of same size and scope with a conventional project organization, and easy to compare with other kindergarten projects built by the same client. Both case projects had the same client, but were conducted by two different vendors. The case projects were studied according to the recommendations by Yin (2009). The main characteristics of the case projects are presented in Table 1.

The literature review formed the basis for the theoretical background and was undertaken using the search engines Oria, Scopus and Google Scholar. Search words such as "best value procurement", "best value approach" and "early contractor involvement" were used. Oria is a Norwegian University library resource. Important documents were used for citation chaining, as described by Wohlin (2014). The objective of the literature study was to develop a theoretical background on how BVP should be performed and to gain insight into previous experiences with the approach. 
Table 1: Case overview and the respective interviewee's position $(\mathrm{C}=$ client's organization, $\mathrm{V}=$ vendor's organization)

\begin{tabular}{ccccc}
\hline Project name & Description & $\begin{array}{c}\text { Project } \\
\text { start-finish }\end{array}$ & $\begin{array}{c}\text { Cost } \\
\text { (USD) }\end{array}$ & Interviewee's position \\
\hline $\begin{array}{l}\text { 1) Munkerud } \\
\text { Kindergarten }\end{array}$ & $\begin{array}{c}\text { Kindergarten } \\
\text { with six } \\
\text { departments }\end{array}$ & $2018-2019$ & $\begin{array}{c}\$ 4.5 \\
\text { mill }\end{array}$ & $\begin{array}{c}\text { Project director }{ }^{\mathrm{C}} \text {, project manager } \mathrm{C}, \\
\text { construction manager/design } \\
\text { manager } \mathrm{V} \text {, project legal advisor } \mathrm{C}\end{array}$ \\
$\begin{array}{c}\text { 2) Vollebekk } \\
\text { Kindergarten }\end{array}$ & $\begin{array}{c}\text { Kindergarten } \\
\text { with eight } \\
\text { departments }\end{array}$ & $2018-2019$ & $\begin{array}{c}\$ 7.4 \\
\text { mill }\end{array}$ & $\begin{array}{c}\text { Project manager } \mathrm{C}, \mathrm{V} \text { and } \\
\text { construction manager } \mathrm{V}, \mathrm{C}, \text { evaluation } \\
\text { committee member } \mathrm{C}\end{array}$ \\
\hline
\end{tabular}

A total of 8 interviews were conducted with key personnel from the case projects. Some of the individuals from the client's organization were involved in both projects, with multiple positions. All positions are listed in Table 1. The first interviews were held in the period October-November 2018 and the follow-up interviews were held in March-April 2019. The interviewees were selected based on their involvement in both the procurement and execution phase of the projects, and they all have managerial positions in the projects. The interviews were conducted through in-depth semi-structured interviews based on an interview guide. No changes were made to the interview guide during the process. All interviews were carried out face-to-face at the interviewee's offices and lasted between 45 minutes to 90 minutes. Each interview was recorded and later transcribed. To verify and quality assure the results, a summary of the interview was sent to the informants for reviewing. After the interviews, a document study was carried out in order to triangulate the results (Yin, 2009). The study included tender documents, contracts and project plans. Data from the interviews were hand-coded and analysed hand-in-hand with the data collection, and findings were written down based on the description of Creswell (2013).

\section{THEORETICAL BACKGROUND}

\section{EARLY CONTRACTOR INVOLVEMENT}

Many measures, systems, and approaches are introduced to improve the productivity of the construction industry. One of these measures is Early Contractor Involvement (ECI). ECI refers to the involvement of a contractor at an early stage of project development, to work together with the client and/or consultant, mainly to assist in planning and buildability (Rahman \& Alhassan, 2012). It is recognized that the ability of the parties to influence project outcomes, including reduction of cost, creation of additional value, improvement of performance and flexibility to incorporate changes is much higher in the conceptual and design stages of the project (Mosey, 2009). ECI can be achieved by several approaches, and one of the approaches is BVP (Wondimu et al. 2018b).

\section{Best Value Procurement}

The overall purpose of BVP is to identify and select the most suitable vendor (the expert) through simple and dominant information (Atosa et al. 2018). The main objectives are to increase profit, minimize use of resources for all parties, minimize decision making and utilize expertise instead of management, direction and control (Kashiwagi, 2016). The 
main reference on how BVP should be implemented is the book written by the originator of the approach - Dean Kashiwagi (Kashiwagi, 2016). However, in the European context, the approach is adapted to fulfil EU public procurement legislation requirements (Högnason et al. 2018). This approach has been used on several Dutch projects and is the approach that Norwegian projects are based upon (van de Rijt et al. 2016). This approach will be further presented in this section.

BVP is separated into four phases: Pre-Qualification phase, Selection phase, Clarification phase, and Execution phase. The Pre-Qualification phase is according to Kashiwagi (2016) optional and consists of training and education in BVP for both client and vendor (Atosa et al. 2018). No solutions are presented during this phase, but all design is performed in the Clarification Phase. The design is performed by the vendor as in a conventional design \& build-contract. Some key elements in this phase are selection and education of a core team, use of an external BV expert, pre-qualification of vendors, preparing a core document, training of client and vendor and calculating the owner's maximum price (Högnason et al. 2018).

The Selection phase is where the client identifies an expert vendor with the highest level of expertise for the lowest cost (Kashiwagi, 2016). The criteria to determine expertise are the Level of Expertise (LE) document, Risk Assessment (RA) document, Value Added (VA) document, project cost and interview of key personnel. Other important elements of this phase are a time-plan for the project, short listing of potential vendors, multiple grading groups and a dominance check of the vendors (Högnason et al. 2018).

The Clarification phase consists of three parts: a kick-off meeting, a clarification part and a contract award meeting. The Clarification phase is described by Witteveen \& van de Rijt (2013) as the most important phase of BVP, and the purpose is to clarify what the vendor will deliver and how they will deliver it. An essential part is therefore to clarify what is in and outside the scope, as well as outlying technical solutions (Atosa et al. 2018). The goal is to clarify whether the offer is acceptable for the client, clarify expectations, identify key performance indicators (KPIs), and finally sign an agreed contract for the project (van de Rijt et al. 2016). KPIs are in many projects found to be difficult, and Kashiwagi (2016) prescribes little information on their design. Guidelines for using KPIs in BVP projects are given by Horstman \& Witteveen (2013). Important elements in this phase are the kick-off meeting, risk management plan, scope document, elaboration of potential critical sub-contractors, KPIs, letter of intent, contract award meeting, involving the vendor in framing of contract, distribution of risk responsibility and risk contingency fund (Storteboom et al. 2017).

The Execution phase is where the project is realized. The overall goal for this phase is to deliver the service or the deliverable, but also to enhance transparency, communicate information quickly, assign accountability and create a supply chain approach in the project organization (Snippert et al. 2015). This is done by implementing Weekly Risk Reports (WRR), Directors Report (DR) and performance measurements using KPIs throughout the execution phase. During this phase, the vendor is also responsible for performing quality control and risk management (Atosa et al. 2018). These are the four main phases as stated by the theoretical framework. The phases with their related elements are summarized and presented in Table 2. 


\section{FINDINGS AND DISCUSSION}

Despite the study being conducted as a longitudinal study, no significant differences or changes were found between the first and second round of interviews. Some additional elements and consequences were though added. The case study results are shown in Table 2 and Table 3. Both tables follow the framework earlier described and published by Högnason et al. (2018) and Storteboom et al. (2017). Table 2 shows that BVP was practiced quite similar in the two projects, and mostly as described by van de Rijt et al. (2016). Both projects implemented most of the elements identified in the literature review, and strived to practice all elements as recommended by Kashiwagi (2016). There are though some differences between the two projects.

In one of the projects the client's maximum price was announced, while the other project chose to announce the client's maximum budget. The difference was whether added value from the vendors were to be included in the tender price or not, and tenders over the maximum budget price were not rejected. The idea was that as a result, the vendors would offer added value as a part of the original tender and not as an additional cost. In the Vollebekk project, added value was therefore not included in the evaluation criteria as it is described by van de Rijt et al. (2016). The interviews displayed that no real added values were achieved in the project. Instead, the client got a kindergarten more or less as expected. The quality was higher than the minimum required, but nothing out of the ordinary. When offered added value, however, the client states they received a building unlike any other kindergarten they have built, with a high level of innovation. Two other important elements were the performance measurements and KPIs, as the vendor is a fairly small and new vendor which normally do not get projects like this. The project was therefore very important for showcasing their expertise and a potential springboard for future project awards.

Table 2: Practicing of Best Value Procurement

\begin{tabular}{lll}
\hline Elements of BVP & Munkerud Kindergarten & Vollebekk Kindergarten \\
\hline Pre-Qualification Phase & & \\
Sponsor & No & No \\
Selection and education of core team & No & No \\
External BV expert & Yes & Yes \\
Pre-qualification & No & No \\
Use of all four phases & Yes & Yes \\
Training of owner & Yes & Yes \\
Core document / request for proposal & Yes & Yes \\
Open budget w/ceiling & Client's maximum price & Client's maximum budget \\
& & price \\
Training of vendor & Yes & Yes \\
\hline Selection Phase & & \\
Evaluation criteria in MEAT: & & \\
$\bullet \quad$ Level of expertise & $15 \%$ & $30 \%$ \\
• Risk assessment & $20 \%$ & $20 \%$ \\
• Added value & $10 \%$ & $0 \%$ \\
$\bullet \quad$ Interview with key personnel & $30 \%$ & $25 \%$ \\
- Price & $25 \%$ & $25 \%$
\end{tabular}




\begin{tabular}{lll} 
Time-plan & Yes & Yes \\
Short listing & No & No \\
Multiple grading groups & No & No \\
Dominance check & Yes & Yes \\
\hline Clarification Phase & & \\
Kick-off meeting & Yes & Yes \\
Risk management plan & Yes & Yes \\
Scope document & Yes & Yes \\
Elaboration of potential critical sub- & No & No \\
contractors & & \\
Key Performance Indicators (KPIs) & Yes & Yes \\
Letter of intent & No & No \\
Contract award meeting & No & No \\
Vendor involved in framing of contract & Yes & Yes \\
Owner financially responsible for all & Yes & Yes \\
controllable risks & & \\
Risk contingency fund & No & No \\
\hline Execution Phase & & \\
Weekly risk report & Yes & Yes \\
Performance measurements & Yes & Yes \\
Director's report & No & No \\
\hline
\end{tabular}

How the different elements of BVP are practiced in the earlier phases has been found to have an impact on the execution phase. Several consequences depend on how BVP is practiced, and the consequences are presented in Table 3. Most of the consequences were positive, but some elements caused a number of challenges for the execution phase or the final product.

None of the projects used pre-qualification and the selection was based on an open competition. The evaluation criteria were thus a vital part of the procurement and has shown to have a large impact on both process and the final product. Including added value as an evaluation criterion has resulted in more innovation, whereas a lack of added value has limited the innovation.

The use of price as an evaluation criterion has shown to be excessive due to the open budget and the owner's maximum price. All tenders were placed on or near the maximum price, and did not contribute to differ the vendors. Price was weighted $25 \%$ in both projects. Future projects must see this as an opportunity to increase the weighting of quality, and hence achieve more quality in the project.

Among the challenges were a lack of interviewees from the vendor participating in the execution phase. In both projects, despite a large focus on using BVP in all four phases of the project, the construction manager first joined the project late in the clarification phase and the interviewees had limited involvement in the execution phase. Important performance from the execution phase was thus not evaluated in the interviews, which must be seen as an important part in the procurement of a vendor. In order to ensure evaluation of the vendor's expertise in the execution phase as well as in the earlier phases, the interviewees should include the construction manager as well as the project and design manager. Including key personnel from the execution phase in the early phases is a vital part of ECI. As earlier stated, BVP is just as much a mind-set as an approach, and needs to 
be shared by all participants. By including the construction manager in the interviews, this mind-set will be strengthened and shared by more personnel in the execution phase.

The interviews further raised an inadequate periodic control and updating of the risk management plan as a challenge. This led to low information regarding the overall project risk, along with the project's budget and time plan. Despite being the vendor's responsibility, it is important for the client to be aware of the overall project risk to minimize the need for control and project follow-up. The WRR has worked well in both projects, but the vendors have not reported weekly throughout the project. The result was a minimal impact on the client's control need. In terms of the overall project risk, it is important to practice a regular periodic control and update of the risk management plan. The goal is to reduce the owner's control needs, as proclaimed by Kashiwagi (2016).

Lastly, the interviewees revealed that an inadequate standardization of KPIs has made it challenging for the parties to develop and use performance indicators. It has especially shown to be difficult to measure innovation and quality in the execution phase - both important factors when evaluating a BVP project. The theory gives few recommendations on which KPIs to use, and Kashiwagi (2016) proclaims they must be established by the project itself. The theory does, however, highlight the contract award meeting as an important element in this process (van de Rijt et al. 2016). The purpose of the meeting is, among other things, to establish and clarify KPIs and project risk. Both projects held a traditional contract meeting, but failed to clarify these elements before the execution phase. Future projects should consider whether or not KPIs should be standardized, and it is important to sufficiently clarify and establish these indicators in the clarification phase, as stated in the theory. Guidelines provided by Horstman \& Witteveen (2013) should be taken into account, and all KPIs must be jointly prepared by both vendor and client. Education and training in BVP plays an important part of this process. The performance measured by the indicators serve as an important evaluation factor in future BVP projects, and must provide dominant information regarding the vendor's performance. This is, as stated in the theory, a key element when selecting a vendor. More of the identified consequences are listed in Table. Only elements found to have an impact on the execution phase or the final product are listed. Elements not listed were still practiced as described in Table 2.

Table 3: Consequences of Best Value Procurement

\begin{tabular}{lll}
\hline Element of BVP $\quad$ Effect & Consequences for the execution phase \\
\hline $\begin{array}{l}\text { Pre-Qualification Phase } \\
\text { Use of all phases }\end{array}$ & + & $\begin{array}{l}\text { Best Value Procurement becomes a mind-set, rather than a } \\
\text { method. Sharing this mind-set leads to a collaborative } \\
\text { environment in the execution phase } \\
\text { More flexible and demand-controlled communication in the } \\
\text { execution phase }\end{array}$ \\
$\begin{array}{ll}\text { Core document } \\
\text { Open budget w/ceiling }\end{array}$ & + & $\begin{array}{l}\text { More predictable solutions for the client } \\
\text { Selection Phase } \\
\text { Evaluation criteria }\end{array}$ \\
& + & Higher weighting of quality leads to higher quality
\end{tabular}


$+\quad$ Added value leads to more innovation

$+\quad$ Opens for new and smaller vendors that normally would not get the project

- A lack of interviewees from the vendors participating in the execution phase may limit the evaluation of the vendor's project execution performance

$+\quad$ More weight on quality leads to a higher focus on investment and life cycle costs

Clarification phase

Kick-off meeting

Key Performance

Indicators

Contract award meeting Execution phase Weekly Risk Report $+\quad$ Gives the actors a common understanding of the project and leads to increased interaction between the parties

$+\quad$ Clarifies playing rules for conflicts and leads to increased construction progress in the execution phase

- Inadequate periodic control and update leads to low information regarding the overall project risk

- Inadequate standardization makes it difficult to develop and use KPIs

- $\quad$ Difficult to measure innovation and quality in the execution phase

- $\quad$ Lack of a contract award meeting may limit the benefits of $\mathrm{KPIs}$ and risk management plan in the execution phase

$+\quad$ More efficient communication in the execution phase Causes no reduction in the owners control needs

Performance measurements and director's report were not found to have a significant impact on the execution phase, but may be of a larger importance in future projects when practiced correctly. Further measures are given in Table 4. In addition to the consequences listed above, the approach has been found to create a strong collaborative mind-set in both projects. At first glance, BVP seems to be just another procurement model. The execution phase is completed according to a standard design \& build contract, and with a normal project organization. However, this study has shown that BVP has improved both the process and product in terms of quality and progress. The vendor has a better understanding of the project and is more prepared when the execution phase is initiated.

Both projects had a delayed start-up due to a slow treatment process by the Planning and Building Services of Oslo Municipality, and for an extended time there was no unified overall time plan for the project. This could in many cases been a great cause of conflict, but the collaborative environment has in both projects contributed to overcoming this challenge in the best possible way. In both projects, the parties have shown flexibility and cooperativeness beyond normal, and the shared mind-set has shown to be a very important consequence of BVP in terms of project success.

\section{CONCLUSIONS}

This paper set out to explore experiences with BVP from two Norwegian public kindergarten projects, in order to answer the following research questions: 1) how was BVP practiced in the project, 2) what consequences followed BVP in the execution phase and 3) how should BVP be practiced in future projects. The study is limited to two public 
kindergarten projects for the same client. Both projects have proven to be successful, and no conflicts or disputes have arisen. The findings are nevertheless found to be transferable to other BVP projects. In general, both projects have practiced the approach as described in the theory. This is further described in Table 2. In many ways, the characteristics of BVP appeared in the earlier phases, and the execution phase was carried out as a conventional design \& build contract. The difference from a conventional project, when it comes to the execution phase, was the mind-set created by the implementation of BVP.

BVP consists of several elements, and it is stated in the theory that the clarification phase is the most important phase before the execution phase. This study has though shown that there are several equally important elements from both the pre-qualification phase and the selection phase. These phases must therefore be seen as equally. How BVP is practiced in the earlier phases has shown to have a significant influence on the execution phase of the project, and thus also the final product. Added value will increase innovation, but may be limited by a specific core document. On the other hand, this may lead to a more predictable product for the client. Despite the execution phase being completed more or less like a conventional execution phase, BVP can improve both the process and product in terms of quality and progress when practiced the correct way. BVP provides a unique mind-set and helps to create a collaborative and flexible project environment among the project parties. Most of the elements have shown to have a positive effect, but some may cause challenges for the execution phase. All consequences are presented in Table 3.

This study has shown that, along with being a procurement model, BVP is also a mindset. This mind-set must be shared by all participants, and especially by those involved in the execution phase. Integrating key personnel from the execution phase is therefore an important measure, and can be achieved by including the construction manager in the selection interviews. This practice will strengthen the evaluation of the vendor's project execution performance - an important part of the procurement process. Education and training of project participants in the BVP method, use of a BVP expert, as well as a thorough and well planned kick-off-meeting, has proven to strengthen this collaborative mind-set. An important part of the kick-off-meeting is to establish trust between participants, an equal understanding of the project's scope, as well as playing rules for potential conflicts. All of them are important measures in future BVP projects.

Other important elements are the core document, time plan, added value, risk management plan, dominance check, KPIs, WRR and performance measurements. Further important measures and improvements for future BVP projects are displayed in Table 4.

Table 4: Improvements and measures for future BVP projects

\begin{tabular}{ll}
\hline Element of BVP & Measure/improvement \\
\hline $\begin{array}{ll}\text { Pre-Qualification Phase } \\
\text { Core document }\end{array}$ & $\begin{array}{l}\text { A clear and precise core document leads to more predictable solutions } \\
\text { for the client but may limit the innovation. Important to early clarify what } \\
\text { is more important for the client. }\end{array}$ \\
$\begin{array}{l}\text { Education of project } \\
\text { participants }\end{array}$ & $\begin{array}{l}\text { BVP is a mind-set more than a method. This mind-set must be shared } \\
\text { by all participants regardless of project phase. Future projects should } \\
\text { have an extensive focus on education in BVP. }\end{array}$
\end{tabular}




\begin{tabular}{|c|c|}
\hline External BV expert & $\begin{array}{l}\text { Frequently involve the BV expert. Costs should be covered by the } \\
\text { owner, not the vendor. }\end{array}$ \\
\hline \multicolumn{2}{|l|}{ Selection Phase } \\
\hline Price & $\begin{array}{l}\text { Price should not be a part of the evaluation criteria when the owner's } \\
\text { maximum budget is specified. Tenders over the maximum price must } \\
\text { be declined. }\end{array}$ \\
\hline Time plan & $\begin{array}{l}\text { May be included as an evaluation criterion when a faster execution } \\
\text { phase is desirable. }\end{array}$ \\
\hline Dominance check & $\begin{array}{l}\text { Perform as early as possible to avoid waste of project resources on a } \\
\text { non-expert }\end{array}$ \\
\hline $\begin{array}{l}\text { Interview of key } \\
\text { personnel }\end{array}$ & $\begin{array}{l}\text { Key personnel from the execution phase must be included. The } \\
\text { practice will make it easier to evaluate project execution performance } \\
\text { and implement the BVP mind-set in the execution phase }\end{array}$ \\
\hline Added value & $\begin{array}{l}\text { Open for vendors to offer Added Value. This will lead to more } \\
\text { innovation in the project. }\end{array}$ \\
\hline \multicolumn{2}{|l|}{ Clarification Phase } \\
\hline Kick-off-meeting & $\begin{array}{l}\text { Establish playing rules for conflicts, trust and an equal understanding } \\
\text { of the project scope. Important actions for preventing potential conflicts }\end{array}$ \\
\hline $\begin{array}{l}\text { Risk management } \\
\text { plan }\end{array}$ & $\begin{array}{l}\text { Periodically control and update of the plan in order to provide an } \\
\text { overview of the overall project risk }\end{array}$ \\
\hline $\begin{array}{l}\text { Key Performance } \\
\text { Indicators }\end{array}$ & $\begin{array}{l}\text { Must be sufficiently clarified and established early in the clarification } \\
\text { phase. }\end{array}$ \\
\hline & $\begin{array}{l}\text { Establish clear indicators for how to measure innovation and quality. } \\
\text { Formed after guidelines by Horstman \& Witteveen (2013). } \\
\text { Must be periodically evaluated and updated during the execution } \\
\text { phase. }\end{array}$ \\
\hline $\begin{array}{l}\text { Contract award } \\
\text { meeting }\end{array}$ & $\begin{array}{l}\text { Clarify and establish final KPIs and expose all risk factors in the project } \\
\text { to achieve a better practice of these elements in the execution phase. }\end{array}$ \\
\hline \multicolumn{2}{|l|}{ Execution Phase } \\
\hline Weekly Risk Reports & $\begin{array}{l}\text { Must be formed to help reduce the client's control needs } \\
\text { Must be completed and sent weekly, whether or not new information } \\
\text { has occurred. }\end{array}$ \\
\hline $\begin{array}{l}\text { Performance } \\
\text { measurements }\end{array}$ & $\begin{array}{l}\text { All actors should measure their own performance in order to gather } \\
\text { dominant information for future projects. }\end{array}$ \\
\hline
\end{tabular}

BVP is still fairly new and unknown in the Norwegian construction industry, and there is a need for more experiences from future BVP projects. In this study, both projects have proven to be successful, and there is little knowledge on how BVP handles conflicts. Furthermore, clients have proven to find it difficult to lose control of the project. To introduce better KPIs and properly use WRRs are therefore important measures for future projects in order to reduce the client's control needs.

This study has been limited to two public kindergarten projects for the same client. Further studies should explore experiences from both private and public clients, and actors such as sub-contractors and consultants. BVP cannot guarantee a successful project and conflicts will always arise in some projects. However, by introducing and following the measures given in Table 4, the chances of a successful project and a better product will increase in future projects. 


\section{REFERENCES}

Atosa, J.; Breivik, I. B.; Wondimu, P.; Houck, L. D. (2018) "Experience with Best Value Procurement in Norwegian Infrastructure Projects” Procedia Computer Science 138, pp. 783-790.

Caruana, E.J.; Roman, M.; Hernández-Sánchez, J.; Solli, P. (2015) 'Longitudinal Studies”. Journal of Thoracic Disease, vol. 7(11), s. 537-540

Creswell, J. W. (2013) Research Design: Qualitative, quantitative, and mixed methods approaches, Sage Publications

Carcía-Pena, C.; Gutierérrez-Robledo, L. M.; Pérez-Zepeda, M. U. (2015) Aging Research - Methodological Issues. Cham: Springer International Publishing.

Horstman, A.; Witteveen, W. (2013) "Performance Indicators in the Best Value Approach" Journal for the Advancement of Performance Information and Value, vol. 5(2)

Hosseini, A.; Wondimu, P.; Klakegg, O.J.; Andersen, B.; Lædre, O. (2018) "Project Partnering in the Construction Industry: Theory vs Practice" Engineering Project Organization Journal, vol. 8, pp. 13-35

Högnason, O.; Wondimu, P. A.; Lædre, O. (2018) "Best Value Procurement - The First Experiences from Norway". Proceedings of the Creative Construction Conference

Kashiwagi, D. (2016). Best Value Approach. Mesa, Arizona: Kashiwagi Solution Model (KSM).

Mosey, D. (2009) Early Contractor Involvement in Building Procurement: Contracts, Partnering and Project Management. 1. edition. John Wiley and Sons.

Narmo, M.; Wondimu, P. A.; Lædre, O. (2018) "Best Value Procurement (BVP) in a mega infrastructure project." Proc. of the 26th Annual Conference of the International Group for Lean Construction, vol. 1, pp. 23-33

Rahman, M. \& Alhassan, A. (2012), “A contractor's perception on early contractor involvement", Built Environment Project and Asset Management, Vol. 2 No. 2, pp. 217-233.

Samset, K. (2014) Prosjekt $i$ tidligfasen. Valg av konsept. 2. edition. Bergen: Fagbokforlaget Vigmostad Bjørke AS

Snippert T, Witteveen W, Boes H, Voordijk H. (2015) "Barriers to realizing a stewardship relation between client and vendor: The Best Value approach." Construction Management and Economics, vol. 33(7), pp. 569-586.

Statistics Norway (2018) Productivity decrease in the building industry [web page] Available from: https://www.ssb.no/bygg-bolig-og-eiendom/artikler-ogpublikasjoner/produktivitsfall-i-bygg-og-anlegg. Downloaded: 24.01.19

Storteboom, A.; Wondimu, P.; Lohne, J.; Lædre, O. (2017) "Best Value Procurement The Practical Approach in The Netherlands." Procedia Computer Science 121, pp. 398406

Tjora, A. (2012) Kvalitative forskningsmetoder i praksis. 2. edition. Oslo: Gyldendal Norsk Forlag AS

Van de Rijt, J.; Santema, S.; Soilammi, A. (2016). Best Value Procurement Prestasjonsinnkjøp. (3. edition - translated from Dutch). Oslo: Rådgivende Ingeniørers Forening. 
Nygård, E. F., Wondimu, P., Lædre, O.

Witteveen, W.; van de Rijt, J. (2013) "Possible Barriers to a Successful Further Diffusion of the Best Value Approach in the Netherlands: Observations of Major Understandings on the Concept and Theory" Journal for the Advancement of Performance Information and Value 5(2)

Wohlin, C. (2014) Guidelines for Snowballing in Systematic Literature Studies and a Replication in Software Engineering. Karlskrona: Blekinge Institute of Technology.

Wondimu, P. A.; Klakegg, O. J.; Lædre, O.; Ballard, G. (2018a) "A Comparison of Competitive Dialogue and Best Value Procurement." Proc. International conference of the international group for lean construction.

Wondimu, P.; Hosseini, A.; Lohne, J.; Lædre, O. (2018b). "Early contractor involvement approaches in public project procurement." Journal of Public Procurement, vol. 18(4)

Yin, R. K. (2009) Case Study Research: Design and Methods. 4. edition. Thousand Oaks (California): SAGE Publications 